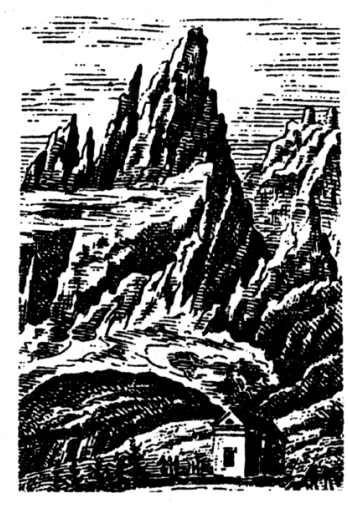

\title{
Agnieszka Straburzyńska-Glaner
}

Uniwersytet Mikołaja Kopernika w Toruniu

agaglaner@gmail.com

DOI: $10.19195 / 2084-4107.11 .27$

\section{Tatry i Zakopane w doświadczeniu Jerzego Żuławskiego}

Słowa-klucze: Tatry, taternictwo, poezja, krajobraz

Keywords: Tatras, mountaineering, poetry, landscape

\section{The Tatras and Zakopane as experienced by Jerzy Żuławski}

\section{Summary}

The mountains, especially the Tatras, occupy a special place in Jerzy Żuławski’s life. As a place where one can escape from the noise and chaos of the civilised world, they become important as one of the most influential spaces shaping the creative personality of the mountaineering writer. The article is an attempt to examine the author of Trylogia Księzycowa (The Lunar Trilogy) from the perspective of a mountain hiker's experiences. The present author analyses both memoirs and journals - which reveal to the readers a lesser known side of Żuławski, an experienced mountaineer, one of the co-founders of the Tatra Volunteer Search and Rescue and activist in Zakopane - and literary works, especially his lyrics, which reveal the writer's wandering predilections and record his authentic experiences of mountain spaces. What emerges from these writings is a symbolic image of the mountains as an area of freedom (also political freedom), a place where God's creative power is revealed, finally - a place of physical and mental liberation, requiring as much courage and 
fortitude as humility in confrontation with the primeval forces of nature. The author of the article, pointing to intertextual references and traces of literary and philosophical tradition (influence of Schopenhauer and Nietzsche, Spinozian pantheism, Romantic images), seeks to demonstrate the individuality of the writer, for whom the ultimate reference in his Tatra oeuvre is always an authentic experience of wandering.

Przełom XIX i XX w. to okres dla kultury i literatury polskiej bardzo szczególny, bo zdominowany zjawiskiem określanym w literaturze przedmiotu mianem „odkrycia Tatr”". Odkrycia osobliwego o tyle, że niemającego większego związku z geografią fizyczną, a ujmowanego przede wszystkim w kategoriach geografii humanistycznej, odnoszącej pojęcie gór i góralszczyzny do semiologii przestrzeni człowieka. U schyłku XIX stulecia sytuacja polskiego taternictwa rysuje się przecież nie najgorzej — góralszczyzna jest już w dużej mierze rozpoznana, a Zakopane coraz bardziej zyskuje na popularności jako cel przybywających na południe kraju turystów. „Odkrywanie” Tatr w tym okresie, dokonujące się w przestrzeni symbolicznej, polegało w pierwszym rzędzie na uczynieniu z gór tekstu kultury, pojęcia, które w powszechnym odbiorze funkcjonowało jako nośnik pewnych trwałych wartości czy idei ${ }^{2}$. Czynnikiem w znacznym stopniu wpływającym na powodzenie tego procesu była sytuacja polityczna kraju, który pogrążony po klęsce powstania styczniowego potrzebował bodźca w postaci możliwie najbardziej realnego, ucieleśnionego mitu wolnościowego:

wszystko, co ujrzano pod Tatrami: przyroda wspaniała, dziewicza, nietknięta, powietrze nieprawdopodobnie czyste, ożywcze, uzdrawiające, lud tutejszy inny niż nizinny: zdolny, zręczny, ambitny, dumny, bystry, jego język jędrny, obrazowy, brzmiący po staropolsku, jego budownictwo piękne a praktyczne, ozdobne a dostojne, jak echa architektury starosłowiańskiej, jego muzyka osobliwa a tak odmienna, jego strój nawet, przypominający starogreckie motywy - wszystko to w danej chwili, po mrokach psychicznego załamania podziałało jak ożywczy, jasny promień, odrodzeńczy wstrząs ${ }^{3}$.

W tej atmosferze przybywa do stolicy Tatr Jerzy Żuławski. Pisarz, wychowany na terenach niedalekiej Ziemi Limanowskiej, odwiedzając Zakopane po raz pierwszy w roku $1895^{4}$, inicjuje swą wieloletnią przygodę z turystyką górską. Od tego roku Tatry i Podhale staną się dla niego tyleż celem, co przestrzenią licznych wędrówek, miejscem szczególnym, jeśli nie kluczowym na mapach jego

1 Zob. J. Reychman, Peleryna, ciupaga i znak tajemny, Kraków 1975, s. 42-43; A. Ziemilski, Człowiek i góry a cywilizacja wspólczesna, [w:] Sympozjum „,Góry w kulturze polskiej”, red. M Broniowska, Kraków 1975, s. 26-27.

2 A. Ziemilski, op. cit., s. 26.

3 J. Reychman, op. cit., s. 43-44.

${ }^{4}$ Swoje górskie wycieczki rozpoczyna Żuławski w tym właśnie roku przejściem przez Zawrat. 
peregrynacji, wreszcie — miejscem, któremu duchowo pozostanie wierny aż po kres swego przedwcześnie zakończonego życia.

Związki Żuławskiego z Zakopanem naznaczone są od samego początku intensywnością i zaangażowaniem. Już w 1903 r. pisarz zostaje taternikiem, a wkrótce po pierwszym taterniczym osiągnięciu, jakim było samotne zdobycie Małej Galerii Cubryńskiej ze Źlebu pod Mnichem5 ${ }^{5}$ następują kolejne ${ }^{6}$. W 1908 r. Żuławski wstępuje w szeregi Sekcji Turystycznej Towarzystwa Tatrzańskiego - sportowego klubu taternickiego, jest także jednym z pierwszych członków Tatrzańskiego Ochotniczego Pogotowia Ratunkowego. Pisarz jest aktywnym członkiem społeczności zakopiańskiej, działającym równolegle na wielu obszarach: jako redaktor lokalnego czasopisma ${ }^{7}$, kierownik artystyczny „Wesołej Budy" — teatru żartu i satyry ${ }^{8}$, założyciel działającego pod patronatem Sekcji Przyjaciół Zakopanego TT — Koła Dramatycznego 9 , jeden z prelegentów tzw. kasyna $^{10}$, ale przede wszystkim aktywny taternik i propagator idei górskiego wycieczkowania.

Mieczysław Świerz, pisząc we wspomnieniu pośmiertnym o sposobie wędrowania Żuławskiego i jego stosunku do Tatr, podkreślał przede wszystkim, że artysta:

5 E. Gawąd, Jerzy Żuławski w Zakopanem, [w:] Jerzy Żuławski. Życie i twórczość, red. E. Łoch, Rzeszów 1976, s. 23.

${ }^{6}$ Pierwsze wejście na Ciemnosmreczyńską Turnię północno-zachodnią granią (1908), wejście na Żabiego Konia, wejście na Gerlach od północy z Kaczej Doliny (1908), zejście ku północnemu zachodowi z Ciężkiej Przełączki (1909), przejście granią przez Smoczą Grań (1909), zdobycie Złomiskiej Turni od strony południowej (1911) oraz pierwsze wejście na Smoczy Szczyt południowo-zachodnim żebrem z Doliny Złomisk (1911). Z. Radwańska-Paryska, W.H. Paryski, Jerzy Żutawski, [w:] eidem, Wielka encyklopedia tatrzańska, Poronin 1995, s. 1455; E. Gawąd, op. cit., s. 31.

7 W latach 1912-1914 Jerzy Żuławski pełnił funkcję redaktora literackiego czasopisma „Zakopane", do jego kompetencji należał najprawdopodobniej dobór tekstów literackich dopuszczanych do druku.

${ }^{8}$ Teatr ten miał swoją siedzibę początkowo we wspomnianej już sali kawiarnianej u Przanowskiego, później zaś — gdy na skutek rosnącego zainteresowania „Budą” warunki lokalowe „u Przana” przestały wystarczać — w przystosowanej do tego celu (wyposażonej w kurtyny i dekoracje) sali hotelu Morskie Oko.

9 Przedstawienie inauguracyjne Koła Dramatycznego odbyło się 18 lipca 1914 r. w Sali „Morskiego Oka” w Zakopanem. Zob. „Zakopane” 1914, nr 13, s. 7.

${ }_{10}$ Powołane do istnienia w roku 1874, pierwotnie z siedzibą nieopodal kościoła, później zaś, w roku 1882, przeniesione do budynku Dworca Tatrzańskiego. „Placówka ta spełniała rolę ówczesnego „domu kultury”, skupiała przybyłych pod Tatry turystów, uczonych i artystów”. Żuławski jako jeden z prelegentów w roku 1899 wygłosił w Zakopanem odczyt o Królu-Duchu Juliusza Słowackiego. Doceniony przez Ferdynanda Hoesicka w szczególności za nowatorstwo oraz śmiałość myśli interpretacyjnej, był przedmiotem gorących dyskusji i wzbudził żywe zainteresowanie zgromadzonej publiczności. W roku 1902 Żuławski wystąpił z cyklem prelekcji O rozwoju sztuki greckiej. Zob. W. Krygowski, Rola Polskiego Towarzystwa Tatrzańskiego w badaniach polskich gór i jego znaczenie kulturotwórcze, [w:] Sympozjum..., s. 18; F. Hoesick, Legendowe postaci zakopiańskie. Wybór z „Tatr i Zakopanego”, Warszawa 1959, s. 561; Wiadomości bieżace, „Przegląd Zakopiański” 1902, nr 36, s. 353.

Góry, Literatura, Kultura 11, 2018

(C) for this edition by CNS 
uciekał od konwenansów i dławiącej banalności miasta, od kagańców sztucznych form współżycia ludzkiego, ukutych z fałszu i zawiści, a hartowanych w ogniu kłamstw i obłudy, od nacisku zewnętrznych przymusów, wtłaczających go w ramy obowiązkowości, troską o chleb - choćby razowy - dnia powszedniego uwarunkowanej; wyrywał się od pańszczyzny, składanej na rzecz egzystencji ze swych sił najlepszych, czyniącej go ząbkiem u kół machiny społecznej, co nakazuje mu bieg okrężny około jednej, zawsze tej samej osi.

U wrót skalnych opadały wędzidła obowiązków, a niebawem groble stawów, potargane granie, upłazy i usypiska przełęczy przysłoniły widok na dalekie niziny, ludzkich mrowisk siedliska. Człowiek stawał wobec świata, któremu obce intrygi i nienawiści, który nie zna potwarzy i potępień, nie ceni według tytułów, rang i przynależności rodowej, nie łamie wzniosłych myśli szyderstwem i nie zakłada nad marzeniem żelaznych krat rzeczywistości ${ }^{11}$.

Góry mają zatem dla Żuławskiego istotny wymiar symboliczny i postrzegane są jako „inne” cywilizacje. Są swego rodzaju mostem wiodącym ku nowym światom, dzięki któremu człowiek może wyłączyć się z biegu życia i zatopić w nieskończoności, nie zatracając przy tym własnej tożsamości, lecz co istotne - tożsamość tę, zagubioną w świecie cywilizacji — na nowo odbudować12. Surowość gór, ich niedostępność, swoboda, prawdziwość i prostota składają się w światopoglądzie pisarza na pojęcie zbudowane z wartości (estetycznych, ale też społecznych i moralnych), wobec których wrażliwy człowiek nie może pozostać obojętny.

Żuławski jako taternik nie był, co warto podkreślić, „dzieckiem gór”, te jednak zajęły w jego życiu miejsce szczególne, czemu zresztą niejednokrotnie dawał wyraz w swojej twórczości literackiej. Dowodem na to, jak bardzo emocjonalnie traktował Tatry, jest sposób, w jaki o nich pisał — zawsze traktował je jako s wo je, jak w liście adresowanym z Morskiego Oka do Czemerys, do żony Kazimiery:

Wybiera się tutaj kilku taterników na szczyty, na szukanie nowych dróg w okolicy Lodowego, — byli tu dzisiaj, chcieli, żebym szedł z nimi, uszom własnym nie chcieli wierzyć, że odmówiłem... Co mi po tym? Nową drogą na Rysy przeze mnie przed dwoma laty wynalezioną, szedł w zeszłym roku tylko jeden człowiek (Staniszewski), spadł i złamał nogę i cztery żebra. Odtąd nikt nie chodzi. — Ale ja sobie pójdę moją

11 M. Świerz, Jerzy Żuławski. Wspomnienie pośmiertne, „Pamiętnik Towarzystwa Tatrzańskiego", Kraków 1916, s. 7-8.

12 O związkach tak odczytywanej filozofii Tatr z buddyzmem pisze J. Reychman, op. cit., s. 163. 
kochaną, moją drogą, zajrzeć jeszcze raz Czarnemu Stawowi w oczy z prostopadłej i popękanej ściany - - - Ja nie spadnę ${ }^{13}$.

Także sposób wycieczkowania Żuławskiego naznaczony jest w dużej mierze pierwiastkiem emocjonalnym, choć zbytnim uproszczeniem byłoby stwierdzenie, że to właśnie jemu podporządkowana jest recepcja gór w kulturowej świadomości autora Erosa i Psyche. Bliższa analiza życia Żuławskiego oraz jego pisarstwa, zarówno z zakresu publicystyki, jak i literatury pięknej, pozwala dostrzec trzy, co istotne — równoprawne, pierwiastki, które składają się na obraz Tatr i Podhala. Są to: kontemplacyjny estetyzm, aktywność sportowa oraz ratownictwo górskie ${ }^{14}$.

Waga doznań duchowych i estetycznych w procesie budowania młodopolskiej fascynacji Podhalem zdaje się nie do przecenienia. Podejście Żuławskiego do eksploracji Tatr w sposób niebudzący najmniejszych wątpliwości stawia pisarza w rzędzie spadkobierców ideowej schedy po Stanisławie Staszicu, Tytusie Chałubińskim, Stanisławie Witkiewiczu, Janie Gwalbercie Pawlikowskim, Władysławie Orkanie czy Walerym Eliaszu-Radzikowskim, którzy, choć tak odmienni, nade wszystko cenili w górach ich wartości metafizyczne. Tym, co charakteryzuje taterniczą filozofię Jerzego Żuławskiego, jest więc

wysiłek zorientowany na osiągnięcie duchowych przeżyć, na poznawanie tajemnicy bytu - i na literaturę. Bowiem w tym pędzie poety do pokonywania przepaści, stromych ścian i niezdobytych szczytów przejawiała się może najlepiej walka człowieka z niebezpiecznym żywiołem skalnym przyrody, a owocem tej walki była radość z odniesionego zwycięstwa i przekraczania granic ludzkich możliwości ${ }^{15}$.

Sama zaś metafizyka gór odległa była w twórczości literackiej Żuławskiego od popularnej w epoce poetyki „drgnień duszy”, której pisarz w istocie pozostawał niechętny. Treści naddane poetyckim krajobrazom górskim wiązały się nierozerwalnie z wyznawaną przez autora filozofią, w której szerokim echem odzywały się głosy spinozjańskiego panteizmu.

Co się zaś tyczy elementu sportowego w taterniczej filozofii autora Laus feminae, to choć sam pisarz ze sporym dystansem odnosił się do odczytywania sensu górskich wędrówek przez pryzmat wyłącznie aktywności fizycznej, to jednak stanowi ona istotny element tej filozofii. Opór przed uznaniem sportowo-zdobywczego wymiaru nowoczesnego taternictwa miał przy tym charakter tendencji bardziej ogólnej i był znakiem właściwego taternikom tego okresu przywiązania do tradycyjnej formuły romantycznej. Nie bez powodu cytowany już Mirosław Świerz z wielką ostrożnością charakteryzował nowatorskie podejście Jerzego Żuławskiego. Pisał:

${ }^{13}$ List Jerzego Żuławskiego do żony Kazimiery z dnia 19.07.1908, [w:] J[uliusz]. Żuławski, Z domu, Warszawa 1978, s. 101-102.

14 J. Majda, Młodopolskie Tatry literackie, Kraków 1999, s. 39.

15 Ibidem, s. 40. 
popęd ku walce z grozą gór - rys dla współczesnej turystyki tak charakterystyczny - cechował w pełnej mierze taternictwo Żuławskiego i dlatego to przedstawiał on typ pośród poetów Tatr nowy, dotąd nieznany: typ - nie wahajmy się użyć tego wyrażenia - sportowca [podkr. A.S.]. Jego sposób wycieczkowania odbijał wszystkie nowe prądy alpinizm i taternictwo nurtujące, zawierał wszystkie składniki współczesnych metod zwiedzania gór ${ }^{16}$.

Także w listach Żuławskiego (dających skądinąd również pojęcie o przekornej naturze pisarza) odnajdujemy wyraźne echa zdobywczej pasji młodego taternika, łączącej sportowy zapał, taterniczą samodzielność i elementy współzawodnictwa z autentycznym duchowym przeżyciem:

Żebyś ty wiedziała — pisał Żuławski w liście do żony — jaka to straszna wariacka rozkosz wyjść pierwszym na niedostępny szczyt i stawiać w takim dziewiczym miejscu gdzieś pod niebem nad przepaściami kopiec własnymi rękoma z kamieni na znak, że szczyt zdobyty! Wyć się człowiekowi chce po prostu! — Niedawno przeszedł tu jeden młody (Staniszewski) grzbiet Miedzianego nie uczęszczaną dotąd drogą i chwalił się strasznie trudnościami, - ja tam na drugi dzień, żeby chwalbę jego wykpić, poszedłem tą samą drogą... z moim psem! $!^{17}$ — Co prawda, gdzie było źle, musiał pies w torbie wędrować! ${ }^{18}$

Warto jednak podkreślić, że styl wędrowania Jerzego Żuławskiego nie jest jednoznaczny i daje się w nim wskazać dwa przeciwległe bieguny ${ }^{19}$. Obok opisanego już przemierzania tras nieznanych, nastawionego na pokonywanie

${ }^{16}$ Ibidem, s. 21. Żuławski z pełnym zaangażowaniem działał w służbie upowszechniania narciarstwa, promując je zarówno własnym przykładem (w 1911 r. odbył wycieczki narciarskie na Goryczkową Przełęcz i Kasprowy Wierch), jak i pisarstwem publicystycznym (m.in. relacjonując na łamach czasopisma „Zakopane” przebieg zawodów narciarskich, które odbyły się na Kalatówkach: idem, II Międzynarodowe Zawody Narciarskie w Zakopanem, „Zakopane” 1911, nr 4, s. 2-3) czy działalnością literacką. W twórczości artystycznej Żuławskiego, któremu przypisuje się wprowadzenie narciarstwa jako tematu w obręb literatury polskiej, odnajdujemy bowiem kilka ciekawych fragmentów. Zob. idem, Profesor Butrym, Warszawa 1916, s. 136, 143. Wątek narciarski pojawia się także w liryku zatytułowanym Zjazd tatrzański — pierwodruk w wydawnictwie zbiorowym Zima i narty, Lwów 1913/14; przedrukowany w wydaniu późniejszym: idem, Wiersze, wyb. i wstęp A. Makowiecki, Warszawa 1982, s. 226. Warto zauważyć, że wprowadzenie przez Żuławskiego do literatury polskiej tematu narciarstwa w jego nowatorskiej, sportowej odsłonie otworzyło zupełnie nowy kierunek w wertykalnym rozumieniu zdobywczego traktowania przestrzeni gór. O ile wcześniejsze realizacje literackie utożsamiały zdobycie góry wyłącznie ze wspinaczką, o tyle zadaniowe postrzeganie zjazdu narciarskiego stworzyło nieobecne dotychczas pole interpretacji ruchu zstępującego.

17 Mowa o ukochanym jamniku, Robaku.

${ }_{18}$ List Jerzego Żuławskiego do żony Kazimiery z dnia 19.07.1908.

19 Co ciekawe, sam Żuławski miał świadomość tego, że jako taternik jest postrzegany przez pryzmat tej dwoistości stylów wędrowania. W liście do żony z dnia 20 września 1908 r. pisał: „Mój syn tak musi chodzić po szczytach! - Chciałbym, aby o nim powiedziano kiedyś, jak tu o mnie

Góry, Literatura, Kultura 11, 2018

(C) for this edition by CNS 
trudności, nie mniej charakterystyczne są dla Żuławskiego typowe włóczęgi, pozbawione aspiracji odkrywczych czy zdobywczych, stanowiące wartość samą w sobie. W samotności, bez przewodnika wędrował Żuławski długimi godzinami po różnych dolinach, z których najbardziej cenił sobie położoną u stóp Mięguszowieckich Szczytów Dolinę Rybiego Potoku z Morskim Okiem:

włóczęgi dolinne, poezją dawnych wypraw opromienione, po koczowiskach po lasach, halach i kolebach, o dniach słonecznych, beztroskich, w których tylko mimochodem zbaczało się czasem na jakąś dziką iglicę, aby przywrócić prężność muskułom i zbudzić instynkty pierwotne, marniejące w miejskich wygodach, a potem móc tym pełniej snuć pieśn radości i zawrotnej swobody życia górskiego ${ }^{20}$.

Żuławskiego jako pieśniarza gór charakteryzuje zatem autentyzm przekazu, dla którego inspirację stanowiło rzeczywiste doświadczenie górskiej przestrzeni. Kształt formalny utworów zdradza oczywiste nawiązania do bogatej tradycji motywu, ostatecznie jednak służy do przedstawienia oryginalnego, autorskiego obrazu świata widzianego oczami wędrowca.

Reprezentatywnym przykładem jest wiersz $\mathrm{Na}$ Gierlachu, będący zresztą czytelnym odniesieniem do znanego z XIV sonetu krymskiego Adama Mickiewicza motywu poety na szczycie ${ }^{21}$ :

Głazy mając pod stopą, a nad głową chmurę,

po stopniach piramidy, która z bożej kielni

wzrosła, gdy jeszcze Jego snem byli śmiertelni,

bez odpocznienia szedłem na najwyższą górę

[...]

Mgłę przebrnąłem... krok jeden! Szczyt! Ha! Ziemska gleba

nieco niżej i ludzie mniejsi, ale nieba

niedosięgłe wciąż wiszą tak samo wysoko ${ }^{22}$.

Podkreślenie monumentalizmu gór potęguje doświadczenie trudu wędrówki, który charakteryzuje tatrzańskie liryki Żuławskiego. O ile jednak większości realizacji pisarza właściwa jest perspektywa zdobywcza (sportowa) — nowatorska na tle badanego nurtu, o tyle w Na Gierlachu uobecnia się ona (głównie poprzez stylistykę i środki poetyckiego obrazowania) w takim kształcie, jaki nadała górom tradycja romantyczna. W zgodzie z nią wertykalnemu ruchowi ciała towarzyszy

jeden z „taterników” powiedział: Żuławski na nudnych drogach wlecze się, ale gdy naprawdę złe miejsce przychodzi, to się orzeł z niego robi, — zdaje się, że ma skrzydła...”, ibidem, s. 104.

20 M. Świerz, op. cit, s. 23.

${ }^{21}$ U Mickiewicza czytamy: U stóp moich kraina dostatków i krasy, / Nad głową niebo jasne, obok piękne lice; / Dlaczegoż stąd ucieka serce w okolice / Dalekie, i — niestety! jeszcze dalsze czasy?

22 J. Żuławski, Na Gierlachu, [w:] idem, Poezje. Wydania zbiorowego w nowym układzie tomów 4, t. 1, Lwów 1908, s. 226. 
pragnienie wzlotu ducha i myśli — pragnienie, które w obrazie Żuławskiego okazuje się jedynie konsekwencją oderwanych od rzeczywistości wyobrażeń na temat istoty świata. Młodopolski pisarz dokonuje bowiem (z właściwym sobie krytycznym podejściem do tradycji historycznoliterackiej) rewizji romantycznego mitu, uświadamiając zarówno sobie (jako poecie), jak i innym niemożność przekroczenia pewnego poziomu percepcji:

i choć chmury-m zostawił na dole, nad mą głową

obłokami zasnute błękity na nowo;

przez nie na świat poogląda mętne słońca oko ${ }^{23}$.

Doświadczenie to ujawnia gorycz zrodzoną z ludzkiej niezdolności do przezwyciężenia ograniczeń, a w wymiarze sensów wyrażeniowych demaskuje romantyczną wiarę w mistycyzm gór wyrażającą się w postrzeganiu ich jako przestrzeni łączącej świat ludzki z Absolutem.

W konsekwencji, w zupełnie nowatorski sposób ujawnia się u Żuławskiego wędrówka jako doświadczenie permanentne. Niepohamowana „żądza wiecznych wstępowań" z ducha Nietzscheańskiego witalizmu splata się w nim z niedającym się przezwyciężyć poczuciem klęski i ograniczenia wędrowca. Świadomość niemożności osiągnięcia satysfakcji, ostatecznego zaspokojenia pragnień zdobywcy sprawia, że celem staje się w istocie samo wędrowanie.

W owym wiecznym nienasyceniu ujawniają się bodaj najsilniej wpływy nowoczesnego pesymizmu Schopenhauerowskiego ${ }^{24}$, któremu najpełniejszy wyraz dał Żuławski w liryku Podróżnik opowiada:

Jest głód szczy tów niesyty, który oszalenia żądzą wiecznych wstępowań. Na góry ogromne wychodziłem, a jednak, zaprawdę! nie pomnę, abym kiedy, wyszedłszy, doznał ukojenia ${ }^{25}$.

Jakkolwiek swego rodzaju wieczna tęsknota, obecna także w przywołanych wersach, właściwa jest wielu tatrzańskim lirykom Żuławskiego, wpływy myśli filozoficznej Spinozy pozwalają poecie przezwyciężyć pesymizm doświadczenia górskiej wędrówki. Przezwyciężenie to dokonuje się na drodze poczucia wolności w wewnętrznym działaniu ${ }^{26}$.

Ambiwalencja doświadczania przestrzeni tatrzańskich sprzyja budowaniu pejzażu górskiego jako swego rodzaju uniwersum przestrzennego. Świat kreowany w omawianych lirykach Żuławskiego jest bowiem często raczej światem górskim w ogóle niż podhalańskim — czy jeszcze ściślej — tatrzańskim, a dopiero wiedza na temat związków pisarza (zwłaszcza emocjonalnych) z Zakopanem oraz

23 Ibidem.

${ }^{24}$ Szerzej o związkach myśli Żuławskiego i Schopenhauera zob. J. Tuczyński, Schopenhauer a Młoda Polska, Gdańsk 1987, s. 158-159.

25 J. Żuławski, Podróżnik opowiada, [w:] idem, Poezje..., t. 1, s. 235.

26 J. Tuczyński, op. cit., s. 159. Por. także wiersze pisarza: J. Żuławski, Za słońcem, [w:] idem, Poezje..., t. 1, s. 53 oraz idem, W świat marzeń, [w:] idem, Poezje I, Warszawa 1901, s. 13. 
dyskretnie wyrażone w utworach wskazówki topograficzne pozwalają widzieć w skałach, turniach czy wodnych kaskadach elementy rodzimej przyrody ${ }^{27}$.

Dająca się wyprowadzić $z$ badanych wierszy geografia serdeczna ${ }^{28} \dot{Z} u ł a w-$ skiego obejmuje oczywiście także w pełni identyfikowalne elementy topografii Tatr, niemniej jednak i one obecne są w tej twórczości w sposób szczególny i nad wyraz oryginalny. Żuławski takimi wierszami, jak W noc na Morskim Oku, Na Mięguszowieckiej Przełęczy, Na Gierlachu, W Dolinie Pięciu Stawów czy Zawrat $w$ mgłach włącza się w tradycję wprowadzania do literatury polskiej miejsc kluczowych z perspektywy nasilającego się ruchu turystycznego i taterniczego.

Morskie Oko z racji niewątpliwych walorów estetycznych oraz uwikłania jego historii i znaczenia w opowieści legendowe już w pierwszej połowie XIX w. należało — obok Doliny Kościeliskiej — do najczęściej odwiedzanych i literacko opiewanych zakątków Tatr. O „Perle Galicji” z różnym zresztą powodzeniem pisali m.in.: Stanisław Duńczewski, Benedykt Chmielowski, Józef Tetmajer, Seweryn Goszczyński, Zbigniew Morawski, Ludwik Zeiszner, Władysław Tarnowski, Wincenty Pol, Teofil Lenartowicz, Bogusz Zygmunt Stęczyński, Jadwiga „Deotyma” Łuszczewska czy Stanisław Wyspiański ${ }^{29}$. Żuławski podjął ten temat trzykrotnie w wierszach $W$ noc na Morskim Oku, Na Mięguszowieckiej Przełęczy oraz Nokturn, przy czym żaden z liryków nie jest literackim opisem jeziora w ścisłym tego słowa znaczeniu. Autor Erosa i Psyche konsekwentnie unika weryzmu przedstawień, kładąc nacisk nie tyle na topografię miejsca, co na doświadczenie przestrzeni, będące udziałem człowieka w niej zanurzonego. W sposobach poetyckiego obrazowania pozostaje Żuławski w zasadzie wierny tradycji literackiej. Nowatorska skądinąd perspektywa nocnego pejzażu ukazana w słowach:

Lśni pod gwiazdami toń jeziora blada

i gór się widma pławią na głębinie;

w bezkres łódź nasza, jak duch, lekko płynie,

a dusza moja tobie się spowiada.

Spowiada ci się w Tatr ogromnej ciszy, choć nie wie, czy ją twoja dusza słyszy... ${ }^{30}$

27 Być może wynika to z prostego faktu, że Żuławskiemu, wytrawnemu taternikowi, górskie szlaki i bezdroża były bardzo dobrze znane. Inaczej niż pisarze rekrutujący się z grona tak zwanych „ceprów”, tudzież osób, które w Tatrach nigdy nie będąc, zmuszone były uwiarygadniać kreowane przez siebie obrazy literackie, unikał on bezpośrednich wskazówek topograficznych.

28 Termin wykorzystany w artykule Idy Sadowskiej (eadem, Geografia serdeczna. O eseistyce podróżniczej Jerzego Żuławskiego, [w:] Zasługi Jerzego Żuławskiego i jego rodu dla literatury $i$ kultury polskiej XX wieku, red. D. Trześniowski, E Łoch, Lublin 2011) wywiedziony został z cyklu felietonów Zygmunta Nowakowskiego, wydanych pod tym właśnie tytułem

29 Zob. J. Kolbuszewski, Obraz Tatr w literaturze polskiej XIX wieku (1805-1889). Funkcja artystyczna motywu przyrody, Kraków 1971, s. 126-163.

30 J. Żuławski, W noc na Morskim Oku, [w:] idem, Wiersze, wyb. i wstęp A. Makowiecki, Warszawa 1982, s. 172. 
wyraża w sposób w znacznym stopniu skonwencjonalizowany typowe dla młodopolan lęki i tęsknoty. Autor podejmuje popularne w literaturze epoki motywy spowiedzi duszy oraz wprowadzoną przez Stanisława Staszica koncepcję Tatr-świątyni, by budując je w oparciu o kontrast nocy i bladej poświaty księżyca multiplikowanej dodatkowo w funkcjonującej w wierszu na prawach zwierciadła tafli górskiego jeziora, przydać sytuacji lirycznej nastroju nostalgii i melancholii. Opis przyrody staje się zatem zaledwie punktem wyjścia dla zarysowania głębi pejzażu wewnętrznego jednostki.

Podobny mechanizm unikania weryzmu można zaobserwować w Na Mięguszowieckiej Przełęczy. W utworze tym pojawia się wprawdzie opis przyrody, jednak jest on zaledwie punktem wyjścia dla werbalizacji nie tyle stanu ducha podmiotu wypowiedzi lirycznej — choć i on pośrednio wyrażony zostaje w wierszu — ile jego relacji z kobietą, adresatką miłosnych uniesień:

Pytasz mnie, pani, com widział tam z góry ${ }^{31}$,

z tej wśród obłoków zawrotnej przełęczy?

Widziałem w dole cichych wód lazury,

co wyglądały jako twoje oczy,

gdy łza je — na mnie zwrócone — zamroczy.

[...]

A bliżej — czarne, w mgłach przepastne turnie,

takie posępne, jako myśli moje,

co ku błękitom spiętrzają się górnie

i zaś, jak skały w toń, tak w oczy twoje

patrzą — i ani wniebowstępną drogą

wznieść się, ni w głębiach zatonąć nie mogą ${ }^{32}$.

Zawarty w powyższych słowach opis przyrody zyskuje swą znaczeniową pełnię dopiero w powiązaniu z rozgrywającym się na ich tle dramatem nieszczęśliwie zakochanego mężczyzny.

Koncept wykorzystania semantycznej paraleli do oddania sytuacji emocjonalnej przebywających w górach kochanków uznał Żuławski za szczególnie udane narzędzie poetyckiej ekspresji i użył go ponownie w odniesieniu do równie malowniczego zakątka Tatr. Wiersz $W$ Dolinie Pięciu Stawów w podobny sposób wykorzystuje opis pejzażu tatrzańskiego sprowadzonego w monologu lirycznym do roli rekwizytu, figury retorycznej, na której zbudowana zostaje

31 Obok nowatorstwa w niewerystycznym przedstawianiu pejzażu tatrzańskiego wiersz $\mathrm{Na}$ Mięguszowieckiej Przelęczy zaskakuje czytelnika oryginalnością perspektywy. W okresie powstawania wierszy z cyklu Pokłosie, a więc w latach 1894-1904, produkcja literacka poświęcona Morskiemu Oku była już na tyle obszerna, że w istocie trudno było o nową jego literacką odsłonę. Wprowadzony przez Żuławskiego do literatury opis jeziora widzianego z Przełęczy Mięguszowieckiej pod Chłopkiem zdecydowanie wyróżniał się z grona tekstów powielających najpowszechniejszą wśród autorów perspektywę Morskiego Oka widzianego od strony moreny czołowej. Zob. J. Kolbuszewski, op. cit., s. 126-163.

32 J. Żuławski, Na Mięguszowieckiej Przełęczy, [w:] idem, Poezje. Wydania ..., t. 4, s. 47. 
wypowiedź adresowana do kochanki. O ile jednak dominantą stylistyczną w $\mathrm{Na}$ Mięguszowieckiej Przełęczy była paralela, o tyle tu obraz liryczny oparty został na gradacji, zwieńczonej dość zaskakującą puentą. W kolejnych słowach podmiot liryczny, obdarzony artystyczną samoświadomością poeta-pieśniarz, wygłasza pean na cześć kreacjonistycznych zdolności człowieka:

Patrz! — zwraca się do kochanki — oto mogę tę skalną pustynię zasiać dla ciebie pieśni mych kwiatami, tęczowe mosty nad wodospadami budować stopom twym i w mgle, co płynie rozwiewna, biała nad zielone hale, rzeźbić ci widma jasne, jak opale! Mogę dla ciebie ożywić te szczyty, mogę na ciemnych wód tych przestwór cichy rzucać, jak gwiazdy, moich znów przepychy i słać świetliste pod twą łódź błękity, przez które duch mój ciebie, jakby dziecię, poniesie kiedyś $\mathrm{w}$ szczęśliwe zaświecie ${ }^{33}$.

Sprawcza moc poety okazuje się jednak w znacznym stopniu ograniczona. Ostatni dwuwiersz (,przedziwnych cudów zdziałać mogę siła, / kromia jednego: byś ty moja była...") odsłania niedoskonałość kreacjonistycznych zdolności człowieka, jałowych w odniesieniu do rzeczywistości pozaliterackiej. Poeta, powołujący do istnienia na wzór Stworzyciela nowe światy, okazuje się bezsilny w starciu z realnym życiem ${ }^{34}$.

Warto podkreślić, że tłem opisanej w wierszu sytuacji lirycznej są Tatry określone wprost mianem skalnej pustyni. Motyw ten, ważny jako metafora o konotacjach metafizycznych i nieprzypadkowo obecny w twórczości Żuławskiego, odnaleźć można także m.in. u Tetmajera (W Tatrach, Limba, Patrzac ku Tatrom, W pustej przestrzeni...), Nowickiego (Tatry, Noc w turniach, Na hali), Zaruskiego (Tatry jako pustynia, Na bezdrożach tatrzańskich), Witkiewicza (Tatry w śniegu oraz Na przełęczy) czy Micińskiego (Nietota). W licznych jego odsłonach znajduje on odmienne literacko zastosowania.

Symbol tatrzańskiej pustyni ma spory rozrzut semantyczny: oznacza teren pusty, martwy, ponury, groźny, bezludny, bezduszny, bezbarwny i bez ruchu, a zarazem teren święty, nieskalany, przeczysty, posiadający swój styl piękna; nie tylko sugeruje pustkę wewnętrzną, lecz również okres poszukiwania duchowej mocy, rozbudowę własnej sfery idealnej, sposobienia się do twórczego czynu, teofanię; pustynia to klucz do za-

33 J. Żuławski, W Dolinie Pięciu Stawów, [w:] idem, Poezje. Wydania ..., t. 4, s. 48.

34 J. Szurek, Tatrzańskie wiersze Jerzego Żuławskiego, „Prace Humanistyczne” 1979, seria I nr 23, s. 14-15. 
gadki bytu, to także żmudna synajska droga narodu do Ziemi Obiecanej, czyli niepodległości ${ }^{35}$.

W realizacji Jerzego Żuławskiego, nawiązującej w czytelny sposób do motywu genezyjskiego, obraz skalnej pustyni jako przestrzeni martwej, surowej i pustej potęguje wrażenie kontrastu i staje się doskonałym tłem do ukazania w pełnej krasie dzieła, jakie zdolny jest wykreować - niestety, wyłącznie w wymiarze konceptualnym — natchniony artysta.

Jakkolwiek pustynny charakter górskich bezdroży pozostawia miejsce dla kreacjonistycznych możliwości człowieka, pierwszym Stworzycielem krajobrazu tatrzańskiego zawsze pozostaje Bóg. Prawidłowość tę podkreślali z wielkim naciskiem rodzimi poeci, dla których literacka i kulturowa sakralizacja oraz teofanizacja Tatr miała wymiar patriotyczny. Echa uobecniania się sprawczej mocy Absolutu odnaleźć można także w twórczości Żuławskiego. W powstałym w 1895 r. wierszu Zawrat w mglach (w literaturze przedmiotu bardziej znany jako Tatry w mgłach), nawiązującym w swej formie do gatunku reportażu, czytamy:

Wszystko sen był. Ta ziemia barwna i bogata, słońce, zieleń i ludzie — wszystko sen był marny

i ułudny. Nic nie ma, jeno mgła skrzydlata.

Bóg-Stworzyciel przyszłymi słońcami ciężarny

zasnął wczoraj — sen Jego światem był. Na nowo

dziś się zbudził, sen-wszechświat w dym się rozwiał czarny... ${ }^{36}$

[...]

I na dany znak chmury zlewające deszcze

rozstąpiły się w górze - a promień słoneczny

padł na głazy przed nami, dżdżem ociekłe jeszcze.

[...]

Pan Bóg podniósł kurtynę. W skłębionym potoku

wicher chmury w dal pędzi; pod tęczową bramą

świat wyłania się z zasłon zdumionemu oku ${ }^{37}$.

Doświadczona przez grupkę wędrowców dynamika klimatu górskiego pozwala spojrzeć na Tatry nie jako na gotowy i skończony owoc sprawczej mocy Boga, ale każe widzieć w górskich ustroniach nieustannie odnawiające się źródło jego świętej obecności. Nawet pozorna cisza, wyrażona w wierszu obrazem za-

35 J. Majda, op. cit, s. 113.

${ }^{36}$ W wydaniach z lat 1908 i 1982 nastąpiła zmiana w tekście: „[...] dziś się zbudził, sen-wszechświat w dym się rozwiał parny...", skutkiem czego ciężar semantyczny został przeniesiony $\mathrm{z}$ atmosfery mroku w kierunku klimatu oniryzmu i niejednoznaczności obrazu.

37 J. Żuławski, Zawrat w mgłach, [w:] idem, Pokłosie, s. 100-101. Wiersz ten z drobnymi zmianami w tekście i pod zmienionym tytułem Tatry $w$ mgłach przedrukowany został także w tomach: Poezje. Wydania ..., t. 4, s. 47 oraz Wiersze, s. 163 n. 
stygnięcia krajobrazu w bezruchu, przesycona jest niemą obecnością rozumianego w duchu Spinozjańskiego panteizmu Boga:

Tatr kamienna pierś ciszą bajeczną oddecha

i skrzy się na słońcu naga, zimna. — Gdzieś przez turnie

płyną Nieskończoności zamyślone echa ${ }^{38}$.

W tym sensie kontemplacja krajobrazu staje się aktem poznania i adoracji samego Boga (niekoniecznie rozumianego osobowo), a górska wędrówka zyskuje znaczenie jako mistyczna, zbawcza pielgrzymka do polskiej Ziemi Świętej.

Dla oddania pełnego obrazu Tatr należy jednak stale pamiętać o jego aksjologicznej niejednoznaczności czy wręcz ambiwalencji, w której literackich opisach pobrzmiewają echa romantycznej wzniosłości. Charakterystyka wyłaniająca się z początkowych wersów utworu zatytułowanego $\mathrm{Na}$ szczycie:

Śnieg dziewiczy pod stopą bielił głaz bezkwietny,

a nade mną był błękit, a obłok pode mną;

tak świat się cały okrył zasłoną tajemną

i był groźny i pusty — choć blaskami świetny ${ }^{39}$.

uświadamia, że z gór, które niosą ducha zbawczej wolności, tchnie także groźny powiew śmierci. Ta z kolei była Żuławskiemu — wytrawnemu taternikowi i aktywnemu działaczowi TOPR-u — aż nadto znana ${ }^{40}$.

Sposób, w jaki autor pisze o śmierci: zawsze z pewną atencją, respektem i powagą, każe widzieć w tych realizacjach popularnego skądinąd motywu coś więcej niż tylko pojemną figurę poetycką. Tematyzowany literacko problem śmierci jest dla Żuławskiego każdorazowo artystycznie skonkretyzowanym obrazem potencjalnie realnych następstw górskiej wędrówki. Aspekt ten powielać będzie Żuławski z dużą konsekwencją, a poszczególne utwory reprezentujące ów nurt różnić się będą przede wszystkim środkami artystycznej realizacji motywu.

W wierszu Zawrat $w$ mgłach śmierć funkcjonuje jako mroczne przeczucie nieustannie obecna, choć jedynie suponowana siła:

Oto weszliśmy w paszczę skalnego potwora

i płyniem ${ }^{41} \mathrm{w}$ górę łożem głazonurtej piargi

śmierć nas wiedzie, — ląd zniknął w morzu chmur, jak zmora ${ }^{42}$.

38 Ibidem, s. 101.

39 J. Żuławski, Na szczycie, [w:] idem, Poezje. Wydania..., t. 1, s. 12.

40 Por. jeden z wielu odczytów J. Żuławskiego zatytułowany Nieco o wypadkach w Tatrach, „Taternik” 1911, nr 2 oraz artykuł W sprawie oceny trudności w Tatrach, ,Taternik” 1910, nr 3.

41 W wydaniach z lat 1908 i 1982 nastąpiła zmiana w tekście: „Oto weszliśmy w paszczę skalnego potwora i wspinamy się w górę łożem głazonurtej piargi śmierć nas wiedzie, — ląd zniknął w morzu chmur, jak zmora”.

42 J. Żuławski, Zawrat w mgłach, s. 100. 
Jej mroczne oblicze nie łagodnieje nawet wówczas, gdy niebo nad Zawratem się rozjaśnia. Śmierć nie odstępuje; czai się, jak gdyby żądając ofiar pośród tych, którzy ośmielili się zakłócić dziewiczy spokój Tatr.

A tam w dole, kotliny przepaścistej urnie, jak gdyby dym ofiarny, co w niebo ucieka, mgła się skłębiła znowu, Tatry ćmiąc powtórnie.

I w kolejnym fragmencie:

Na skalnym zrębie w blaskach słonecznych skąpani słyszeliśmy krok cichy tej tajemnej mary, co się ku nam skradała w mgle, jak żbik, po grani ${ }^{43}$.

Ważnym środkiem, za pomocą którego udało się autorowi spotęgować wrażenie demonizmu śmierci, jest personifikacja. Dzięki niej abstrakcyjnej sile przydany został pierwiastek materialności w jej ludzkim wyobrażeniu.

$\mathrm{Z}$ jeszcze większą siłą, choć w zgoła odmiennym tonie przemawia do człowieka śmierć w wierszu Głos z przepaści pochodzącym z tomu Pokłosie:

Ponad przepaścią stanąłem na grani,

a Śmierć mówiła do mnie tak z otchłani:

„Nie jestem straszna! Wy życiu wierzycie,

a wszakże lepsza jestem ja niż życie.

Życie was pędzi przez ból i zawody;

we mnie kojąca krynica ochłody [...]"44.

W słowach tych wybrzmiewają raz jeszcze echa Schopenhauerowskiego pesymizmu. Zgodnie z duchem i konwencjami artystycznymi epoki czytelna antynomia życie-śmierć waloryzuje drugą ze wskazanych wartości, określoną w liryku mianem tkliwej, cierpliwej matki. Warto jednak zauważyć, że i tu silnie zaznacza się indywidualizm Żuławskiego, u którego inaczej niż u Kazimierza Przerwy-Tetmajera (Nie wierzę w nic, Ja, kiedy usta..., Hymn do Nirwany), Stanisława Korab-Brzozowskiego (O, przyjdź), Bronisławy Ostrowskiej (Prom) czy Kazimiery Zawistowskiej (Znużenie) człowiek nie jest tym, kto wybiera śmierć bądź niebyt, lecz tym, kto opierając się jej powabowi, rusza w dalszą drogę.

Osobną grupę stanowią w twórczości autora Na srebrnym globie utwory, dla odczytania których można z powodzeniem zastosować klucz biograficzny. Esej Za zwłokami Klimka Bachledy ${ }^{45}$ oraz dedykowany Antoniemu Banasiowi post

43 Ibidem, s. 102.

44 J. Żuławski, Głos z przepaści, [w:] idem, Poezje. Wydania..., t. 4, s. 51.

45 Esej opublikowany został w czasopiśmie „Zakopane” 1910, nr 20-21, a następnie przedrukowany pod nowym tytułem Śmierć bohatera w tomach Miasta umarłe (1918) oraz Eseje (1960). Przebieg opisanej przez Żuławskiego ekspedycji ratunkowej analizuje także Adrianna Dominika Sznapik, [w:] Tatrzańska arkadia. Zakopane jako ośrodek artystyczno-intelektualny od około 1880 do 1914 roku, Warszawa 2009, s. 273-274. 
mortem wiersz Nad grobem przyjaciela ${ }^{46}$ stanowią ciekawe przykłady utworów okolicznościowych. Odnoszą się one do realnie istniejących postaci i autentycznych wydarzeń, które w życiu autora pozostawiły piętno trudnego doświadczenia bliskości śmierci i w jej konsekwencji — bolesnego osamotnienia. Bardziej niż jakiekolwiek inne uświadamiają one żywy związek twórczości z biografią poety-taternika.

Omówione przykłady wskazują na ambiwalencję pejzażu górskiego. Można zatem zadać sobie pytanie o przyczyny tak rozbieżnego obrazu Tatr w różnych artystycznych realizacjach. Odpowiedzialna za ten stan rzeczy będzie poniekąd zmienność samego krajobrazu, którego dynamikę podkreślał Żuławski wielokrotnie. Jednak dla autora, który na szczyty patrzył okiem i sercem humanisty, z perspektywy doświadczeń obcującego z nimi człowieka ważniejsza była, jak można przypuszczać, perspektywa znaczeń nadawanych w procesie recepcji. Ciekawie aspekt ten uzmysławia sytuacja liryczna wiersza Nevermore.

W utworze reprezentującym erotyki tatrzańskie Żuławskiego pojawia się bohater, który wraz z odmianą losu zmuszony jest dokonać częściowej rewizji poglądów na temat znaczenia Tatr w jego życiu. O ważnych dawniej górskich szczytach, świadkach miłosnych uniesień, dziś z nutą goryczy mówi jako o niedostępnym śnie:

To sen był wszystko! Te podniebne góry, te zakochane u stóp ich jeziora

i te gdzieś w bezmiar niosące nas chmury, ta hal słoneczność, te borów ogromy

i te potoków modlitwy z wieczora:

to sen był wszystko, krótki i znikomy.

Ani ja ciebie w życiu kiedy zoczę,

ani ty wspomnisz kiedy moje imię,

choć przez tatrzańskie szliśmy podobłocze razem, choć dłoń twa drżała w mojej dłoni, gdy nad przepaście schyleni olbrzymie, niebo i stóp swych widzieliśmy w toni ${ }^{47}$.

Góry znaczą więc dla podmiotu lirycznego tyle, ile przeżycia, których w ich otoczeniu niegdyś doznawał.

Nastrojotwórczy charakter Tatr pojawia się jako motyw w twórczości Żuławskiego stosunkowo często. Z takich wierszy, jak Kwiat na szczycie, Czarodziejskie słowo, Dumka, Sen Wigilijny w lesie, Wjesieni ${ }^{48}$, We mgle czy Kaskada wyłania się obraz górskiej przyrody jako swego rodzaju organizmu, który żyjąc własnym rytmem, oddziałuje na przebywającego w otoczeniu natury człowieka.

46 Zob. J. Żuławski, Nad grobem przyjaciela w idem, Poezje I, s. 154-157.

47 J. Żuławski, Nevermore, [w:] idem, Poezje. Wydania..., t. 4, s. 50.

48 J. Żuławski, W jesieni, [w:] idem, Poezje I, s. 10-12. 
Budowana nastrojowością miejsc sakralizacja Tatr nie zawsze odnosi się jednak do sacrum rozumianego na sposób chrześcijański — zdecydowanie częściej służy ukazaniu polskich gór jako przestrzeni wyjątkowej, transcendentnej, nieprzeniknionej, skrywającej odwieczne tajemnice. Okoliczności, w których zostają one zdradzone duszy ludzkiej, odnoszą się najczęściej do pozornie błahych zdarzeń górskiej codzienności: powiewu wiatru, szumu drzew, woni kwiatów na halach, pojawienia się obłoków czy porannej rosy. W tej apoteozie codzienności ujawnia się natura jako wyrazicielka mistycznych treści ${ }^{49}$.

Niekiedy, jak w wypadku wiersza Sen wigilijny w lesie, metafizyka Tatr zyskuje dodatkową motywację. Oniryzm i magię gór potęguje sakralny — w rozumieniu chrześcijańskim - wymiar świętego czasu, w którym dokonują się rzeczy niezwykłe. Wobec ciszy, która zeszła na świat w noc wigilijną, na bohatera lirycznego wiersza spływa błogi, kojący sen:

[...] i taka wielka była w świecie głusza, że-m spoczywał, jak na dnie bezbrzeżnego morza, i spała ma dusza...

Śniłem, że ożył nagle stary bór: wszystkie jodły powstały z śnieżnego podłoża i szły w górę przez lśniące lodowców bezdroża olbrzymów czarny sznur!

Szumiały: Pan się rodzi, Pan wszego przestworza!...

A wtem mnie zbudził szum anielskich piór

i zorza! $-\_^{50}$

Co niezmiernie ciekawe, zakończenie wiersza - moment wybudzenia ze snu — nie odbiera przedstawionej sytuacji znamion niezwykłości. Dzięki takiemu rozwiązaniu można sądzić, że transcendencja górskiego świata — wyrażona w obrazie ożywającej natury - wykracza ponad rzeczywistość sennego marzenia i jako taka stanowi dla obecnego w przestrzeni tatrzańskiej człowieka źródło poznania samego Boga.

Górską naturę rozumianą jako żywy organizm Żuławski ukazuje najczęściej poprzez wykorzystanie środków animizacji oraz personifikacji. One właśnie w sposób najbardziej dosłowny, a zarazem wyrazisty pozawalają na przedstawienie dynamiki życia przyrody przy jednoczesnym oddaniu głębi jej transcendentalnych znaczeń. Niekiedy autor wykorzystuje środki bardziej dyskretne, kreuje światy, w których wewnętrzne życie tatrzańskiej przyrody motywowane jest prawidłami natury, jak np. cykliczność pór roku w wierszu $W$ jesieni („Ach przekwitty już kwiaty, / smutna jesień nadchodzi, / uciekł bocian skrzydlaty / tam, gdzie wicher nie chłodzi, / śnieżnych nie ma burz") bądź powołuje obrazy, w których animizowana przyroda zestawiona zostaje w wyraźnej paraleli z naturą ludzką, której charakterystykę w istocie stanowi:

49 Por. J. Żuławski, Czarodziejskie słowo, [w:] idem, Poezje. Wydania ..., t. 4, s. 49.

50 J. Żuławski, Sen wigilijny w lesie, [w:] idem, Intermezzo, Kraków 1897, s. 13. 
Hej! jak kłosy na boisku

pod ceprami mrą, tak me pieśni, nie dla zysku wyśpiewane, lecz dla woni, w ludzkich rękach schną!

[...]

I na zasiew nie zostanie ani jeden kłos;

na mej duszy bujnym łanie nie ostoi źdźbło zielone przed żelazem kos: wszystkie pieśni w krąg zsieczone, wszystkim jeden los! ${ }^{51}$

W takich realizacjach zostaje wydobyta przede wszystkim symbioza, emocjonalna więź człowieka z przyrodą.

Spośród szerokiej gamy środków i figur stylistycznych, za pomocą których Żuławski kreuje pejzaże tatrzańskie, warto wyróżnić ten, który dla wierszopisarstwa autora jest na tyle charakterystyczny, że staje się w pewnym sensie jego znakiem rozpoznawczym. Kaskada — bo o niej mowa - pojawia się w twórczości Żuławskiego wielokrotnie i pełni w niej różne role: jako jeden z ważniejszych elementów natury, jako tytuł jednego z wierszy i tytuł obejmującego dziewięć liryków cyklu (w zbiorze Intermezzo) oraz — jako kategoria poetycka — dla nazwania oryginalnej formy metrycznej utworu lirycznego. W cytowanym już wierszu Marzenie odnaleźć można taki oto obraz:

Ponad spienioną siadam kaskadą w słowików nocną wsłuchan rozmowę, a róże polne u stóp mi kładą w ciernie wplątane kwiaty różowe.

Śpiewem się poję, oddycham wonią, piersiami lasów zachwytam tchnienia; myśli bezładne za światy gonią, płyną pod ciemne niebios sklepienia ${ }^{52}$.

W scenie tej człowiek przebywający w górach zostaje niejako wprzęgnięty w bieg dzikiej natury. Obraz oplatającej nogi wędrowca róży symbolizuje jego zawłaszczenie dla biosfery tatrzańskich szczytów, w konsekwencji czego pomiędzy $\mathrm{z}$ jego egzystencją a egzystencją natury dokonuje się pełna symbioza istnień ${ }^{53}$.

Ideą istnienia człowieka w przestrzeni dzikiej, górskiej natury jest pełne, duchowe doświadczenie sacrum Tatr rozumianego w duchu Spinozjańskiego

51 J. Żuławski, Dumka, [w:] idem, Poezje. Wydania..., t. 4, s. 83.

52 J. Żuławski, Marzenie, [w:] idem, Poezje. Wydania..., t. 4, s. 23-24.

53 Por. także J. Żuławski, Kwiat na szczycie, [w:] idem, Poezje. Wydania ..., , t. 4, s. 273. 
panteizmu. Jego obecność suponowana jest przede wszystkim poprzez kreację bogatej audiosfery, na którą składają się zarówno dźwięki (śpiew ptaków, szum górskiego potoku), jak i — w większym nawet stopniu — znacząca cisza. Figura kaskady buduje $w$ tych przedstawieniach wizualną i audialną dynamikę górskiej przestrzeni, przy czym dynamika ta jest na tyle subtelna, że nie burzy wewnętrznej harmonii, wręcz przeciwnie - dzięki swoistej miarowości, powtarzalności w oddziaływaniu na ludzkie zmysły — sprzyja jej osiągnięciu.

Znaczeniowa pojemność figury kaskady okazała się dla Żuławskiego na tyle inspirująca, że zastosował ją nie tylko jako motyw literacki, element konstytuujący świat poetycki wierszy tatrzańskich, lecz w oparciu o cechy kaskady, rozumianej jako spadający z kilku stopni skalnych górski wodospad, zbudował oryginalny, sobie właściwy system metryczny wiersza, którego literacką wykładnię dał w zamykającym cykl poetycki liryku tytułowym $Z$ kaskad $^{54}$ :

Pieśń w trzy spadki złamana, bystrych słów kaskada, leci, jak srebrne piany górskich wód!

Pierwszym taktem zmieszanym, niby nimfa blada, tajemnice wydarte głębiom opowiada, -

lub płacze, jakby sylfów ród kropli siostrzanej jednej żałujący, obłąkanej, zwiedzionej, odbitej od stada, straconej i mrącéj...

Pieśnią z wichrowych wyśpiewaną nut, która $\mathrm{z}$ jodeł szczytami nad strumieniem gada, zwrotka druga zaszumi - i z hukiem upada zwalonych burzą kłód.

Trzecia - już się nie skarży, lecz do snu się składa, jak smutna, ścięta tchem zimowym w lód kaskada $^{55}$.

Pod pojęciem kaskady jako formy metryczno-kompozycyjnej rozumie zatem Żuławski utwór liryczny o trójdzielnej strukturze stroficznej, bliski sonetowi i rondu, w którym spójności treściowej następujących po sobie zwrotek odpowiadałby daleki od powtarzalności schemat porządku metrycznego ${ }^{56}$.

${ }^{54} \mathrm{Na}$ cykl ten składają się następujące utwory: Do pieśni, Bóg, Fałszywe proroki, Królewski syn pieśni, Sen wigilijny w lesie, Wieczorem, W jesieni, Nad Aara, Kaskada.

55 J. Żuławski, Kaskada, [w:] idem, Intermezzo, s. 17.

56 Schemat opracowany przez: M. Grzędzielska, Kaskada, „Zagadnienia Rodzajów Literackich” 1964, z. 2, s. 152. Liczby we wzorcu oznaczają liczbę sylab, a litery — układ rymów.

$\begin{array}{lll}13 \mathrm{Ar} & \text { II } 10 \mathrm{~B}^{\prime} & \text { III } 13 \mathrm{~A} \\ 10 \mathrm{~B} \mathrm{~B}^{\prime} & 13 \mathrm{~A} & 10 \mathrm{~B}^{\prime} \\ 13 \mathrm{~A} & 13 \mathrm{~A} & 3 \mathrm{Ar} \\ 13 \mathrm{~A} & 6 \mathrm{~B}^{\prime} & \\ 8 \mathrm{~B} & \\ 11 \mathrm{C} & & \\ 13 \mathrm{~A} & & \\ 6 \mathrm{C} & & \end{array}$


Metrum kaskady wyróżniało się niewątpliwie oryginalnością, jednak nie przyniosło autorowi — poza zamieszczonymi w Wierszach polskich uwagami Jana Łosia $^{57}$ — większego uznania. Formy tej nie podjął żaden z późniejszych twórców, a i sam Żuławski wkrótce jej zaniechał; ponadto przygotowując do edycji kolejne wydania poezji, usunął z nich Kaskady. Wobec takiej postawy autora możemy odczytywać ów epizod — próbę ustanowienia własnego układu stroficznego - jako ambitny, lecz niezbyt fortunny przejaw poddania się młodego jeszcze pisarza popularnym w epoce tendencjom parnasistowskim ${ }^{58}$.

Kaskada, rozumiana zarówno jako wzorzec kompozycyjno-metryczny wiersza, jak i należąca do repertuaru motywów akwatycznych figura poetycka, stanowi w twórczości autora Erosa i Psyche jeden z tych elementów kreacji pejzażu tatrzańskiego, który nie burząc harmonii przedstawionego świata, służy jego poetyckiej dynamizacji. W celu oddania pełni ambiwalencji świata Tatr sięgnął Żuławski także i do tych figur, które akcentowałyby jego mistyczną statykę.

W repertuarze środków, które autor upodobał sobie w sposób szczególny, istotne miejsce zajmuje motyw mgły. O tym, jak ważny był on w twórczości Żuławskiego, świadczy choćby częstotliwość jego pojawiania się w kolejnych utworach tatrzańskich. Tytuły Zawrat (Tatry) w mgłach, We mgle, W górach we mgle czy Nokturn to wybrane, choć nie wyczerpujące bogatego zbioru reprezentatywnych tekstów realizacje.

Jedno z najciekawszych i zarazem najbardziej oryginalnych ujęć prezentuje wiersz zatytułowany Nokturn. Nowatorska jest w nim przede wszystkim perspektywa pogrążonego w mgle nocnego pejzażu tatrzańskiego:

Zastygły skał gromady w miesiąca poświacie,

Śpią złomy granitowe, by dumne zamczyska.

Ogromy turni znikły w mgły promiennej szacie

— Zda się dusza jest duszy wichrów bratnia, bliska ${ }^{59}$.

Krajobraz, którego rysy, zatarte mgłą białej poświaty, mienią się w impresjonistycznej grze księżycowego światła i mroku czarnej, górskiej nocy, ukazany został jako istniejący w ludzkim doświadczeniu w pełnej ulotności i momentalności chwili. Eteryczna, wszechobecna cisza tej przestrzeni sprzyja nastrojowi kontemplacji w poczuciu emocjonalnej więzi z otaczającą naturą. Jej duchową konsekwencją jest osiągnięcie przez człowieka stanu metafizycznej prajedni, świadomości kosmicznej sfery bytu ${ }^{60}$.

Zakończenie wiersza odsłania ponadto rzadki w tatrzańskich wierszach autora patriotyczny wymiar tego stanu. Słowa: „W taką noc się słyszy kamiennych

57 Zob. J. Łoś, Wiersze polskie w ich dziejowym rozwoju, Warszawa 1920, s. 344-345.

58 Ibidem, s. 152-153.

59 J. Żuławski, Nokturn, [w:] idem, Wiersze, s. 225.

60 J. Majda, op. cit., s. 40. 
rycerzy. / I w zaklętej królewny wolno tonąć oczach" nawiązują do znanej, popularnej także w twórczości innych pisarzy ${ }^{61}$ legendy o zaklętym w podziemiach Giewontu wojsku (wariantywnie pojawiają się tu rycerze Bolesława Chrobrego lub też Bolesława Śmiałego), które trzyma pieczę nad losami kraju i które gdy tylko miara zła i ludzkiej niesprawiedliwości się przebierze - powstanie, by zaprowadzić pokój ${ }^{62}$.

Okoliczności społeczno-polityczne w epoce Młodej Polski przesądziły, że legendę o uśpionych rycerzach odczytywano najczęściej jako mit zbrojny, na podstawie którego ewokowano obrazy przyszłości uciemiężonego narodu ${ }^{63}$. Perspektywa Żuławskiego jest szersza; nie zawęża roli bohaterów legendy do konkretnego projektu wyzwoleńczego, lecz poprzez kreację uśpionego, pogrążonego we mgle i noszącego w sobie ukryte wspomnienie historii świata przedstawionego uruchamia czasoprzestrzeń mityczną, przenosząc tym samym ciężar interpretacji $\mathrm{z}$ ducha poezji tyrtejskiej w stronę pojemnego symbolu mitycznej prajedni.

Cechą wspólną wszystkich opartych na motywie mgły realizacji Żuławskiego jest perspektywa myślowej alienacji bohaterów. Nie zawsze jednak towarzysząca jej kontemplacja waloryzowana jest pozytywnie. Zdecydowanie częściej gęsta, amorficzna, nieprzenikniona mgła przydaje obrazowi charakteru trudnego do wyjaśnienia, lecz wyraźnie odczuwalnego ciężaru. W powieści Powrót obraz pogrążonego w mgle krajobrazu funkcjonuje jako zapowiedź duchowych rozterek bohatera:

Mgły się zaczęły kłębić, wzgórze ponad Czarnym Stawem, szarawe, ledwo widoczne, wysuwały się wzwyż i niknęły, uderzone wiatrem, co od Rysów spadał. Jeden kłąb oderwał się w dole od potoka poniżej wodospadu i szedł w górę po limbach, po głazach, podobny z daleka w nocy do jakiejś niekształtnej, olbrzymiej, przygarbionej postaci, na piętro skalne wstępującej... W pustać straszliwą, na czarną, wśród głazów i nocy zagubioną wodę...

${ }^{61}$ Legendowy temat śpiących rycerzy odnaleźć można m.in. u Władysława Orkana (w opowiadaniu Śpiacy rycerze oraz w wierszu Zaśnięci), Andrzeja Stopki (Rycerze śpiacy w Tatrach), Stanisława Wyspiańskiego (w Bolesławie Śmiałym), Stanisława Witkiewicza (w Na przełęczy), Zofii Urbanowskiej (w Róży bez kolców), Tadeusza Micińskiego (w Nietocie), Jana Kasprowicza (w gawędach $Z$ Tatr) oraz Kazimierza Przerwy-Tetmajera (w Na Skalnym Podhalu). Na podstawie fabuły podania powstała także sztuka teatralna Śpiący Rycerze w Tatrach, której autorem jest Sydon Friedberg. Zob. także F. Ziejka, Z dziejów literackiej sławy śpiących rycerzy, „Pamiętnik Literacki”, 1983, z. 2 oraz M.J. Olszewska, Człowiek w świecie Wielkiej Wojny. Literatura polska z lat 1914-1919 wobec I wojny światowej. Wybrane zagadnienia, Warszawa 2004, s. 157-158.

62 Zob. J. Krzyżanowski, Polska bajka ludowa w układzie systematycznym, t. 2, Wrocław 1963, s. 234-236.

63 Zob. J. Majda, op. cit., s. 210-229. 
Turski w niezrozumiały dla siebie sposób przygnębiony był dzisiaj przez cały dzień - i drażniło go to, że nie umiał znaleźć powodu tego przygnębienia ${ }^{64}$.

$\mathrm{Z}$ jeszcze większą siłą, z wyraźnym podkreśleniem pozorności ogarniającej świat ciszy wyrażony zostaje demonizm mgły w jednym z liryków:

Po jasnych upalnych dniach,

po krwawej burzy

świat cały utonął w mgłach

i spokój jest jak śmierć głęboki... ${ }^{65}$

Statyczność przestawionego w wierszu obrazu świata okazuje się — zgodnie z zawartą w inicjującym liryk fragmencie myślą — jedynie iluzją. Kontrast pomiędzy barwnym pejzażem tatrzańskim a uniemożliwiającą przestrzenną orientację bezgraniczną bielą spowitego mgłą świata to jedynie skazana na niepowodzenie próba ochronienia duszy przed bodźcami pochodzącymi ze świata zewnętrznego rozumianego w duchu pesymizmu Schopenhauera.

Mgła jako szczególny przykład motywu akwatycznego w literaturze (jej wodna proweniencja nie jest oczywista ${ }^{66}$, lecz w plastycznych obrazach płynnego, falistego, ruchu, głębi i podobnego morzu bezkresnego charakteru kształtowanej przez nią przestrzenności zostaje przez Żuławskiego wyraźnie zasygnalizowana) okazuje się narzędziem szczególnie przydatnym do oddania ducha młodopolskiego pesymizmu. Potwierdzenie tej tezy odnajdujemy w kolejnych autorskich realizacjach motywu w wierszu Zawrat w mgłach:

A mgły coraz gęściejsze nad nami się ścielą;

na złomie głazu, zda się w otchłanie wszechświata

płyniem nad przedstworzenną mgławych wód topielą ${ }^{67}$.

oraz w utworze $W$ górach we mgle:

Białe morze, białe morze,

w morzu przepadł świat, -

a ty przy mnie, - jasne zorze,

biały morza kwiat,

kwiat zaklęty, wybujały,

niedosięgły kwiat mój biały...

wkoło białe morze.

Chmury płyną, chmury płyną,

pełne dżdżu jak łez, -

64 J. Żuławski, Powrót, s. 122.

65 J. Żuławski, We mgle, [w:] idem, Poezje. Wydania..., t. 4, s. 276.

66 Jan Majda (Młodopolskie Tatry literackie) nie wymienia jej w podrozdziale poświęconym Tatrom w kreacji akwatycznej.

67 J. Żuławski, Zawrat w mgłach, s. 100. 
(nie mojaś ty, o dziewczyno!)

gdzież tym chmurom kres? ${ }^{68}$

Determinizm czasu i ludzkiej egzystencji, monotonia przepełnionego bólem i cierpieniem życia ludzkiego, emocjonalna pustka, a w przypadku ostatniego z przytoczonych liryków także formalne ukształtowanie wypowiedzi poetyckiej (powtarzalność, regularna rytmika wiersza) stanowią przykłady zastosowania obrazowania akwatycznego i języka poezji tatrzańskiej w celu oddania nastrojów dekadenckiego zwątpienia i pesymizmu ${ }^{69}$.

Choć wiersze $\mathrm{z}$ tej grupy nie stanowią bynajmniej wyjątku w tatrzańskim dorobku Żuławskiego, dający się wyprowadzić choćby z prywatnej koresponden$\mathrm{cji}^{70}$ osobisty stosunek autora do gór pozwala widzieć w literacko wyrażonym dekadentyzmie Tatr jeśli nie pozę, to przynajmniej echa konsekwentnie przezwyciężanego i sporadycznie dochodzącego do głosu nastroju zwątpienia. O ile bowiem pesymizm nizin (świata kultury) pojawia się w tej twórczości stosunkowo często, o tyle przestrzeń tatrzańskich szczytów (natury) - ukazana w opozycji — funkcjonuje na zasadzie wyłączonego spod praw ziemskich azylu, w którym ukojenia szuka rozedrgana, łaknąca spokoju dusza ludzka ${ }^{71}$.

Niezależnie od ideowego czy stylistycznego zróżnicowania poszczególnych utworów cechą wspólną literackich obrazów Tatr u Żuławskiego jest prymat procesualności ich poznawania i doświadczania. Pisarza nie interesują w zasadzie góry jako takie, toteż nie dokonuje on w swej twórczości aktów deskrypcji natury, lecz skupiając się na perspektywie poznawczej, przedstawia Tatry jako zapośredniczone w doświadczeniu człowieka-wędrowca ${ }^{72}$. Żuławski, patrząc na szczyty,

68 J. Żuławski, $W$ górach we mgle [w:] idem, Poezje. Wydania ..., t. 4, s. 45.

69 Zob. J. Szurek, op. cit., s. 16-17.

70 W liście z dnia 20 września 1908 r. Jerzy Żuławski pisze do żony Kazimiery: „[...] Gdybyś Ty wiedziała, jak mi się strasznie chciało być z Tobą w tych ostatnich, cudownych, jesiennych dniach przy Morskim Oku... Spadły śniegi, ale zostały tylko na górach. Niżej stopniały — i pod białymi szczytami złociły się w słońcu pożółkłe hale, poniżej czarny kosodrzew, gdzieniegdzie przerywany jakimś płomiennoczerwonym krzakiem liściastym... [...] Miewałem takie dziwne dnie... Wyobraź sobie przez godzinę taką wściekłą walkę ze skałami i przepaściami, o jakiej nie masz, mimo bytności w Alpach, najmniejszego pojęcia, gdzie już nie każdy krok, ale każdą piędź gruntu trzeba w szalonym i śmiałym trudzie zdobywać, — a potem nagle szczyt, — człowiek się przytula do głazu, — zapomina, że tam otchłań zionie wokoło, że tam będzie trzeba znów zejść, — i tylko chwyta słońce pełnymi usty i patrzy spod przymrużonych powiek w ten daleko zjawiony kraj snu, baśni, światła... Tak się strasznie cicho robi na duszy — a czasem coś płakać w człowieku zaczyna, ale cicho, cichutko. A potem żelazny hak wbija się w granitową szczelinę, przewleka się 20, 30 metrów liny przez pierścień i wprost na dół, w przepaść — na taki maluśki stopieniek, gdzie noga się ledwo zatrzyma, aby wywlec linę, nowy hak wbić i znów na dół! A jak wicher czasem szarpnie człowieka i zakręci z liną nad przepaścią jak piórko marne! - A! Jakie człowiek wtenczas ma mocne dłonie! trzyma się, jakby kleszczami stalowymi!”. List przedrukowany w tomie: J[uliusz] Żuławski, Z domu ..., s. 104.

71 Por. wiersz autora pt. Na szczycie.

${ }^{72} \mathrm{~W}$ ten sposób twórczość Żuławskiego wpisuje się w proces ewolucji literatury tatrzańskiej, której schemat w opozycji do zaproponowanego przez Andrzeja Z. Makowieckiego modelu zmian

Góry, Literatura, Kultura 11, 2018

(C) for this edition by CNS 
sięga znacznie dalej - krajobraz jest dla niego zaledwie punktem wyjścia dla złożonej i bogatej refleksji filozoficznej. Tematem jego wierszy tatrzańskich będzie zatem najczęściej procesualnie ukazany akt zdobywania gór (Na Gierlachu, W boru, Myto, Za stońcem, Zawrat (Tatry) w mgłach czy - w wariancie odmiennego kierunku wertykalnego procesu zdobywania - Zjazd tatrzański) i w nich obcowania (Laus feminae, Sen wigilijny w lesie, W Dolinie Pięciu Stawów, Gtos z przepaści, Marzenie, Nokturn, W noc na Morskim Oku, Kwiat na szczycie). Jeśli natomiast literacki pejzaż Tatr przyjmuje znamiona opisu natury, to poprzez formę ukazania gór jako istniejących w ludzkiej pamięci (Na Mięguszowieckiej Przełęczy, Nad grobem przyjaciela, Nevermore) bądź też z wyraźnym zaakcentowaniem jego niestałego, impresyjnego charakteru. Stąd tak znaczny udział obrazowania wykorzystującego motywy atmosferyczne czy akwatyczne.

Cechą znamienną tatrzańskich liryków Żuławskiego jest także ich ideowa poliwalentność, zauważalna często, co ciekawe, nawet w obrębie konkretnych realizacji. Obraz Tatr, daleki od jednoznaczności, budowany jest na opozycjach: życie-śmierć, piękno-groza, statyka-dynamika, dzięki którym góry w swej psychologicznej i estetycznej złożoności stają się w sensie symbolicznym równorzędnym partnerem przebywającego w ich otoczeniu człowieka.

O tym, w jaki sposób Tatry obecne są w twórczości Żuławskiego, w znacznej mierze przesądził fakt pozaliterackich doświadczeń pisarza. Tematyka podhalańska w jego dziełach nigdy nie była wyłącznie odbiciem popularnych tendencji, lecz jako wyrastająca z autentycznych doświadczeń poety-taternika wyróżniała się na tle mnogiej produkcji literackiej ponadprzeciętnym profesjonalizmem ujęcia kwestii taternickich oraz autentyzmem literackiego przekazu ${ }^{73}$.

w zakresie sposobów statyczno-dynamicznego ujęcia przyrody w dziele literackim przedstawił Jacek Kolbuszewski. W myśl badacza wyparcie utworów o charakterze krajobrazowym czy wręcz informacyjnym tekstami, w których pierwiastek tatrzański zostaje sprowadzony — tak jak u Żuławskiego - do roli czynnika nastrojotwórczego, ,akompaniującego” wiąże się z procesem geograficznego rozpoznania Tatr.

73 Jednym z wyznaczników owego autentyzmu była — widoczna zarówno w utworach literackich, jak w listach czy publicystyce — postawa głęboko uczuciowego zaangażowania autora w sprawy zarówno duchowe jak społeczne, ujawniająca się ze wzmożoną siłą w obawie utraty tego, co emocjonalnie bliskie. Jako propagator idei taternictwa i turystyki górskiej Żuławski doświadczał już pierwszych negatywnych konsekwencji postępującej urbanizacji Zakopanego w postaci upadku materialnego oraz kulturalnego dorobku Tatr, kryzysu rodzimej tradycji, bogatego folkloru i obyczajowości, czemu wyraz daje w jednym z liryków:

A przy watrze na ziemi siedzi juhas stary, -

szklistym okiem w płonące zapatrzył się głownie,

wzdycha często, głęboko, smutno niewymownie:

przed oczyma snadź dawne snują mu się mary.

Na twarz orlą, twarz sępią, zmarszczoną i dziką

blaski ognia się kładą przelotne i krwawe,

a on szepce żałosną jakąś słów muzyką:

Góry, Literatura, Kultura 11, 2018

(C) for this edition by CNS 
Doświadczenie taternicze pozwoliło autorowi na uczynienie górskiej wędrówki jednym z kluczowych tematów tej twórczości, który dzięki bezpośredniej znajomości materii nie tracił z biegiem lat na czytelniczej atrakcyjności, wiarygodności i sile poetyckiego wyrazu, lecz przeciwnie - powracał w kolejnych realizacjach w niesłychanej wręcz mnogości odsłon. Mimo upływu lat pozostawał Żuławski niezmiennie zafascynowany monumentalnością i malowniczością górskiego pejzażu; odkrywał je w kolejnych dziełach po wielokroć, akcentując dynamizm i wewnętrzne życie skalnego świata. Jakkolwiek sporo uwagi poświęcał opisom przyrody, traktował je jako punkt wyjścia do głębszej refleksji filozoficznej, której celem było dotarcie do jądra człowieczeństwa. Każdy utwór stanowi zatem zapis mentalnej wędrówki, ważnej — podobnie jak fizyczne trasy — nie tylko ze względu na ostateczny cel, lecz także przez wzgląd na procesualnie postrzeganą drogę dochodzenia do prawdy o istocie i kondycji świata i człowieka.

» Przedam halę, hej! przedam, — pójdę ku dolinie, -

wilków nie ma już w Tatrach, zbójniki w Orawę

już nie chodzą i juhas wnet ostatni zginie...«

J. Żuławski, W szałasie, [w:] idem, Poezje. Wydania ..., t. 1, s. 262. 